Jurnal Nisbah Vol 1 Nomor 1 Tahun 2015 | 1

\title{
KONSEP SERVICE EXCELLENCE PERBANKAN SYARIAH BERDASARKAN AL-QUR'AN
}

\section{CONCEPT OF ISLAMIC BANKING SERVICE EXCELLENCE BY THE QUR'AN}

\author{
M. Zainul Wathani1a Afiati Kurniasih ${ }^{2}$ \\ 1Jurusan Ekonomi Islam Fakultas Perbankan Syariah Universitas Djuanda, Jl. Tol Ciawi No. 1, Kotak \\ Pos 35 Bogor 16770. \\ 2Jurusan Perbankan Syariah Fakultas Ekonomi Islam Universitas Djuanda, Jl. Tol Ciawi No. 1, Kotak \\ Pos 35 Bogor 16770
}

(Diterima oleh Dewan Redaksi: 14-02-2012)

(Dipublikasikan oleh Dewan Redaksi: 01-06-2015 )

\begin{abstract}
Service excellence is the main key of Islamic banking in doing bussines. Good service will make costumer satisfaction, positive word of mouth, and loyality of costumer. On the contrary, bad service will give bad effects such as the angry of the costumer, negative worm of mouth, or costumer will use another bank services. This research study is combination of library and action research by using descriptive qualitative method. It used primary and secondary data. Primary data were obtained through interview and standard operating procedures (SOP) of service excellence in BTN and BJB Syariah. Secondary data were obtained from books, journal and the other resources that are related with the research.

The result of this study shows that service excellence based on the Qur'an is devided in to three aspect : aqidah, akhlak and muamalah. Some guidances of service excellence concept based on Al-Qur'an there are : the employees have to imitiate Rasulullah SAW in giving service to the costumer (chapter Al-Ahzab verse 21), give service gently, having forgiveness character, and Tawakkal to the result (chapter Ali Imran verse 159) give good greetings to the costumer, provide quick service, give service sincerely, have good appareance, and being patient in giving service (chapter Al-Muddatstsir verse 1-7).
\end{abstract}

Keyword : Service excellence, Al-Qur'an

\section{ABSTRAK}

Service excellence merupakan salah satu kunci sukses perbankan syariah dalam menjalankan usahanya. Pelayanan yang baik akan menjadikan nasabah merasa puas, positive word of mouth, dan loyal kepada bank. Metode yang digunakan dalam penelitian ini adalah deskriptif kualitatif yang datanya terdiri dari data primer dan data sekunder. Data primer berasal dari hasil wawancara dan buku panduan pelayanan BTN Syariah dan BJB Syariah. Data sekunder berupa buku, jurnal dan referensi-referensi lain yang terkait dengan pembahasan penelitian.

Berdasarkan hasil penelitian, dapat disimpulkan bahwa konsep service excellence perbankan syariah berdasarkan Al-Qur'an terdiri dari 3 aspek yaitu aqidah, akhlak dan muamalah. Beberapa panduan Al-Quran mengenai pelayanan perbankan syariah yaitu karyawan harus mencontoh bagaimana Rasul melayani pelanggan ketika berdagang (Surat Al-Ahzab ayat 21), karyawan harus melayani nasabah dengan lemah lembut, 
memiliki sifat pemaaf, dan tekad yang kuat (Surat Ali Imran ayat 159). Karyawan juga harus menyapa nasabah dengan baik, memberikan kecepatan dalam melayani, melayani dengan ikhlas, menjaga penampilan dan kebersihan, dan sabar dalam melayani (Surat Al-Muddatstsir ayat 1-7).

Kata kunci : Service excellence, Al-Qur'an.

Wathani M Z. 2014. Konsep Service Excelence Perbankan Syariah Berdasarkan Al-Qur'an. Jurnal Nisbah (1):1 - 22.

\section{PENDAHULUAN}

Al-Qur'an merupakan kitab suci yang kekal dan mukjizat Ilahi yang diturunkan untuk seluruh umat manusia. Turunnya Al-Qur'an pada saat awal turunnya ditanggapi dengan keraguan oleh Kafir Quraisy. Hal tersebut terbukti dengan ejekan, hinaan, siksaan serta tuduhan kepada Rasulullah SAW bahwa beliaulah yang membuat Al-Qur'an. Menanggapi keraguan Kafir Quraisy tersebut, Allah memerintahkan Rasulullah SAW menantang Kafir Quraisy untuk menandingi Al-Qur'an, merekapun tidak mampu menanggapi tantangan tersebut.

Tantangan Rasulullah SAW kepada Kafir Quraisy untuk menandingi Al-Qur'an terdiri dari tiga tahapan yaitu (Hasbi: 2010)

1. Tantangan untuk membuat yang semisal dengan Al-Qur'an

Artinya :"Katakanlah: "Sesungguhnya jika manusia dan jin berkumpul untuk membuat yang serupa Al Quran ini, niscaya mereka tidak akan dapat membuat yang serupa dengan Dia, Sekalipun sebagian mereka menjadi pembantu bagi sebagian yang lain". (QS. Al-Isra : 88)

2. Tantangan untuk membuat sepuluh surat saja seperti Al-Qur'an

Artinya "bahkan mereka mengatakan: "Muhammad telah membuat-buat Al Quran itu", Katakanlah: "Kalau demikian), Maka datangkanlah sepuluh surat-surat yang dibuat-buat yang menyamainya, dan panggillah orangorang yang kamu sanggup (memanggilnya) selain Allah, jika kamu memang orang-orang yang benar". (QS.Hud : 13)

3. Tantangan untuk membuat satu surat saja seperti satu surat dalam Al-Qur'an.

Artinya: "Dan jika kamu (tetap) dalam keraguan tentang Al Quran yang Kami wahyukan kepada hamba Kami (Muhammad), buatlah satu surat (saja) yang semisal Al Quran itu dan ajaklah penolong-penolongmu selain Allah, jika kamu orang-orang yang benar. Maka jika kamu tidak dapat membuat(nya) dan pasti kamu tidak akan dapat membuat(nya), peliharalah dirimu dari neraka yang bahan bakarnya manusia dan batu, yang disediakan bagi orangorang kafir". (QS. Al-Baqarah : 23-24)

Ibnu Katsir menjelaskan bahwa tantangan pada surat Al-Baqarah ayat 23 dan 24 merupakan tantangan yang paling tegas dan sempurna. Dalam ayat ini Allah SWT berfirman فإن لم تفعلو او لن تفعلوا . "Maka jika kamu tidak dapat membuatnya dan tidak akan dapat melakukannya". Kata is merupakan penegasan masa akan datang yang berarti sekali-kali tidak akan ada yang mampu melakukannya (Abdullah :2007). Garansi dari Allah yang menyatakan bahwa tidak akan ada yang mampu membuat satu surat seperti AlQur'an merupakan bukti bahwa Al-Qur'an merupakan pedoman yang terbukti kebenarannya. Pedoman yang ada dalam Al-Qur'an sangat komprehensif dengan 
menjelaskan segala aspek kehidupan termasuk didalamnya aspek ekonomi seperti etika berbisnis, pendistribusian harta secara adil, larangan riba, dan lainlain.

Kegiatan ekonomi merupakan kegiatan yang sangat berhubungan dengan perbankan. Perbankan dalam kegiatan ekonomi memiliki peran yang sangat penting yaitu sebagai lembaga intermediatary yang menyalurkan dana dari masyarakat yang memiliki kelebihan dana kepada masyarakat yang kekurangan dana. Selain itu, ada beberapa peran perbankan yang menujukkan betapa pentingnya keberadaan perbankan dalam perekonomian yaitu menyediakan mekanisme dan alat pembayaran yang lebih efisien dalam kegiatan ekonomi, mendukung permodalan, mendukung kelancaran transaksi internasional, penyimpanan barang-barang berharga dan pemberian jasa-jasa lainnya.

Keberhasilan perbankan dalam melakukan kegiatan usahanya tidak lepas dari pelayanan prima yang diberikan oleh perbankan. Perbankan harus mampu memberikan pelayanan prima karena pelayanan prima merupakan salah satu faktor utama dalam memberikan kepuasan kepada nasabah (consumer satisfaction). Adanya pelayanan yang buruk dan tidak sesuai standar yang diinginkan nasabah dapat menyebabkan nasabah merasa tidak puas. Ketidakpuasan nasabah atas pelayanan yang diterima dapat menimbulkan kemarahan nasabah, Negative Word of Mouth (WOM), berpindahnya nasabah ke bank lain serta efek-efek buruk lain yang akan mempengaruhi keberlangsungan usaha bank (bussines sustainability). Survey yang dilakukan oleh Mobius Management Systems telah membuktikan bahwa pelayanan yang buruk menyebabkan 60\% nasabah melakukan pembatalan akun dengan bank dan 35\% berganti penyedia kartu kredit (Finalist $1^{\text {st }}$ IsEFEF:2012).
Permasalahan service excellence merupakan hal yang mutlak untuk diperhatikan. Bank harus terus memperbaiki kualitas pelayanannya untuk dapat bersaing dalam persaingan antar bank. Persaingan antar bank saat ini sangat tinggi, hal ini menyebabkan perubahan paradigma nasabah dalam pemilihan sebuah bank. Nasabah datang ke bank tidak hanya sekedar menyetor dan menarik dana, melainkan juga membeli suasana dan menikmati kualitas pelayanan yang diberikan oleh bank (Sapri : 2013).

Ada banyak cara yang telah dilakukan setiap bank dalam memperbaiki kualitas pelayannya. Setiap bank biasanya memiliki konsep yang berbeda-beda dalam mengembangkan konsep pelayanan mereka misalnya Bank Mandiri mengusung konsep layanan yang informatif, akurat dan cepat, dalam pelaksanaan konsepnya tersebut Bank Mandiri membentuk SQLO yaitu Service Quality Liaison Officer untuk mengawasi praktek service excellence di lapangan. Bank Internasional Indonesia (BII) memiliki program STAR, singkatan dari Service Oriented, Target Oriented, Assurance and Responsive dengan motonya 'serve with care'. Bank Central Asia (BCA) memiliki konsep pelayanan yang disebut SMART (Sigap, Menarik, Antusias, Ramah dan Teliti) yaitu konsep yang dijabarkan dengan sikap dan etika yang bisa diukur dengan smart reward. Bank Mega menuangkan konsep pelayanannya dalam moto "we love our costumer"( Fadjar Ari Dewanto).

Perbankan syariah sebagai lembaga keuangan syariah juga turut memperhatikan pelayanan prima. Persaingan implementasi pelayanan prima antar bank syariah merupakan bukti bahwa perbankan syariah sangat memperhatikan kualitas pelayanan yang mereka berikan. Marketing Research Indonesia (MRI) dan majalah online infobanknews.com setiap tahun 
melakukan penilaian terhadap kualitas pelayan perbankan syariah tersebut. Penilaian kualitas pelayanan dibagi menjadi delapan kriteria penilaian, yaitu : satpam, teller, costumer service, peralatan banking, hall, kenyamanan ruangan, ATM, toilet, dan telepon. Pengukuran nilai delapan kriteria tersebut tidak berbeda dengan pengukuran untuk bank konvensional.

Persamaan standarisasi kriteria penilaian pelayanan prima perbankan syariah dengan perbankan konvensional perlu ditelusuri kembali ketepatannya. Seharusnya perbankan syariah memiliki kriteria, indikator dan parameter yang berbeda, karena secara fundamental, filosopi dan sistem perbankan syariah sangat berbeda dengan perbankan konvensional. Perbankan syariah dalam menerapkan konsep pelayanan prima harus memperhatikan nilai-nilai yang terkandung dalam Al-Qur'an. Hal tersebut yang mendasari penulis untuk merumuskan pertanyaan penelitian sebagai berikut :

1. Bagaimana konsep Service Excellence BTN Syariah dan BJB Syariah.

2. Bagaimana konsep dasar pelayanan menurut Al-Qur'an.

3. Bagaimana Proses Pelayanan Bank Syariah Berdasarkan Al-Qur'an.

4. Bagaimana Pelayanan Terhadap Nasabah Berdasarkan Al-Qur'an.

5. Bagaimana Relevansi Konsep Service Excellence Perbankan Syariah dengan Konsep Service Excellence Berdasarkan Al-Qur'an.

6. Bagaimana Implementasi Konsep Service Excellence Al-Qur'an pada Perbankan Syariah.

\section{MATERI DAN METODE}

\section{Jenis dan Objek Penelitian}

Metode penelitian yang digunakan pada penelitian ini adalah adalah metode penelitian deskriptif kualitatif. Penelitian deskriptif kualitatif adalah penelitian yang bertujuan untuk menggambarkan hal-hal yang berhubungan dengan keadaan sesuatu dengan jalan mengumpulkan data, menyusun dan mengklasifikasinya (Nadzir : 2005).

Objek penelitian pada penelitian ini adalah Bank Tabungan Negara (BTN) Syariah dan Bank Jabar Banten (BJB) Syariah, dengan fokus penelitian adalah konsep service excellence. Pemilihan BTN Syariah sebagai objek penelitian karena BTN Syariah sangat memperhatikan program service excellence. Pada tahun 2013 BTN Syariah menyediakan dana sebesar 2 milliar untuk program service excellence Pola Prima (Subanda:2013). Sementara itu, pemilihan BJB Syariah sebagai objek penelitian karena BJB Syariah merupakan salah satu Bank Daerah Syariah terbesar di Indonesia dan peraih award "GOOD" Service Perfomance, CALL CENTER AWARD 2012 for service excellence (BJB Syariah : 2012).

\section{Jenis dan Sumber data}

Jenis dan sumber data yang digunakan dalam penelitian ini adalah:

a. Data Primer

Yaitu data yang diperoleh langsung dari objek penelitian. Data primer dalam penelitian ini berasal dari buku panduan pelayanan BTN Syariah dan BJB Syariah, hasil wawancara dengan karyawan, dan penyebaran angket/kuesioner kepada nasabahnya.

b. Data Sekunder

Yaitu data pendukung berupa informasi yang bersifat ilmiah dan teoritis, seperti buku, jurnal, dan literatur-literatur lain yang berkaitan dengan pembahasan penelitian.

\section{Teknik Pengumpulan data}

Untuk memperoleh data pada penelitian ini maka penulis menggunakan metode-metode:

a. Teknik kepustakaan yaitu mengumpulkan data melalui buku, 
referensi, artikel, dan literatur yang sesuai dengan topik penelitian (Kamilah : 2013).

b. Wawancara yaitu pengumpulan informasi dengan cara tanya jawab langsung dengan responden untuk memperoleh data-data yang diperlukan, dan berpedoman pada pertanyaan-pertanyaan yang telah dipersiapkan sebelumnya ( Nazir : 1983).

c. Observasi yaitu metode pengumpulan data melalui pengamatan dan peninjauan secara langsung di lapangan atau lokasi penelitian ( Alhifni : 2011). Tujuan observasi ini adalah untuk memperoleh gambaran nyata tentang penerapan pelayanan di BTN Syariah dan BJB Syariah cabang Bogor.

\section{Teknik Analisis Data.}

Teknik analisis yang digunakan pada penelitian ini adalah analisis kualitatif. Analisis kualitatif adalah analisis berupa penjelasan data dengan uraian kalimat. Penjelasan data pada penelitian ini terdiri dari 4 tahapan yaitu :

a. Penjelasan konsep service excellence perbankan syariah saat ini. Penjelasan tentang konsep service excellence perbankan syariah akan dijelaskan berdasarkan panduan pelayanan BTN Syariah dan BJB Syariah, hasil wawancara dengan karyawan dan data kuesioner yang disebarkan kepada nasabah.

b. Penjelasan konsep service excellence berdasarkan Al-Qur'an yaitu penyusunan konsep service excellence perbankan syariah yang disusun berdasarkan pemilihan ayat-ayat Al-Qur'an tentang service excellence . Ayat-ayat tersebut terdiri dari ayat tentang konsep dasar pelayanan, kepuasan nasabah, dan bagaimana pelayanan terhadap nasabah (konsumen) yang akan dijelaskan dengan menggunakan metode tafsir Alma'tsur (riwayat) dan tahlily (analisis).

c. Penjelasan tentang relevansi konsep service excellence perbankan syariah dan Al-Qur'an. Penjelasan ini berupa kajian terhadap penerapan konsep service excellence perbankan syariah yang ditinjau berdasarkan ayat-ayat AlQur'an tentang service excellence.

d. Penjelasan implementasi konsep service excellence Al-Qur'an perbankan syariah. Penjelasan ini merupakan penjelasan tentang konsep service excellence Al-Qur'an yang telah diterapkan di perbankan syariah. Hal ini dijelaskan melalui penelitian yang dilakukan di BTN Syariah dan BJB Syariah

\section{HASIL DAN PEMBAHASAN}

\section{Konsep Service Excellence BTN Syariah}

a. Pedoman Pelayanan BTN Syariah. BTN Syariah memiliki buku panduan standar pelayanan yang biasa dikenal dengan standar layanan angka 8. Angka 8 diambil sebagai filosopi pelayanan BTN Syariah karena angka 8 memiliki garis yang tidak terputus, menunjukkan sebuah proses yang tak pernah berhenti. Hal ini mengandung makna bahwa BTN Syariah akan terus berusaha tanpa henti untuk mewujudkan palayanan yang prima. Dalam mewujudkan pelayanan prima, BTN Syariah menetapkan kompetensi yang harus dimiliki karyawan. Kompetensi tersebut beragam dan disesuaikan dengan klasifikasi jabatan karyawan di BTN Syariah. Kompetensi tersebut terdiri dari sejumlah pengetahuan, keterampilan, dan sikap yang 
diperlukan setiap karyawan sesuai dengan tugasnya masing-masing.

Kompetensi biasanya terbagi atas kompetensi inti (core competency), kompetensi teknis (technical competency) dan kompetensi perilaku (soft/behavioral competency). Kompetensi inti (core competency) adalah kompetensi yang wajib dimiliki oleh setiap karyawan dalam perusahaan dan seringkali merupakan perwujudan dari nilai-nilai (value) perusahaan. Kompetensi teknis (technical competency) adalah kompetensi yang melekat kepada aktivitas kerjanya, sedangkan kompetensi perilaku (soft/behavioral competency) adalah karakteristik personal yang diperlukan individu untuk menjalankan peran dalam ruang lingkup jabatannya. Ketiga Kompetensi yang terdiri dari skill, attitude, dan knowledge bisa diperoleh dan dikembangkan oleh karyawan melalui pendidikan, pelatihan, penugasan individu yang sistematis, dan coaching counseling (BTN : 2011).

\section{b. Program Peningkatan Kualitas Pelayanan BTN Syariah.}

Dalam upaya meningkatkan kualitas pelayanan kepada nasabah, ada beberapa bentuk kegiatan yang dilakukan Bank BTN Syariah (Taufik Kurohman) :

1) Program SMART (Reading Discussion Product Knowledge) yaitu program penjelasan mengenai produk BTN Syariah yang dilakukan secara bergiliran oleh karyawan BTN Syariah. Program ini bertujuan agar setiap karyawan memiliki pengetahuan produk perbankan syariah yang baik. Kegiatan ini merupakan kegiatan rutin yang dilakukan setiap kantor cabang BTN Syariah setiap jam 07.10-07.30 pagi. Setelah itu, para karyawan menyiapkan kebutuhan kerja, dan semuanya harus siap sebelum kantor kas dibuka pada pukul 08.00 .

2) Roleplay yaitu permainan/game yang diperagakan oleh frontliner untuk meningkatkan kualitas pelayanan yang diberikan kepada nasabah. Kegiatan ini waktunya bervariasi di setiap kantor cabang BTN Syariah.

3) BTN Syariah menyediakan kartu saran sebagai alat monitoring aspek pelayanan (banking hall, atm, satpam, customer service dan teller) yang senantiasa akan dinilai langsung oleh nasabah. Kartu saran adalah media petugas customer service untuk meminta referensi kepada nasabah eksisting tentang apa saja yang perlu diperbaiki dari pelayanan yang telah diberikan oleh BTN Syariah.

4) Setiap bulan BTN Syariah melakukan pemilihan karyawan teladan di setiap kantor cabang. Karyawan teladan ini dipilih melalui vote yang diberikan oleh setiap pegawai kantor cabang. Karyawan peraih penghargaan karyawan teladan tersebut akan mendapatkan bingkisan dari Branch Manager. Hal ini dimaksudkan untuk memotivasi karyawan untuk memberikan kinerja yang maksimal pada setiap pekerjaan yang dilakukannya.

\section{Konsep Service Excellence BJB Syariah}

a. Pedoman Pelayanan BJB Syariah

BJB Syariah memiliki Standard Operating Procedure (SOP) dalam memberikan pelayanan kepada nasabah. SOP 
pelayanan BJB Syariah berbentuk buku yang berisi rincian teknis pelayanan. Teknis pelayanan tersebut mencakup pernyataan visi dan misi pelayanan, prosedur pelayanan, penampilan karyawan, attitude karyawan, prasyarat pelayanan, ketentuan tarif, jenis layanan, janji layanan dan kompetensi yang harus dimiliki setiap karyawan sesuai dengan jabatan.

SOP Pelayanan yang dibuat oleh BJB Syariah memiliki tujuan menjaga kualitas pelayanan yang diberikan bank kepada nasabah. Selain itu, SOP juga berfungsi untuk menyamakan pelayanan di setiap kantor BJB Syariah (Hasabah : 2014). Kesamaan tersebut meliputi bagaimana cara menyambut nasabah, menangani keluhan nasabah dan sebagainya.

\section{b. Motto Pelayanan BJB Syariah}

BJB Syariah memiliki moto pelayanan "I Care" yang berarti "aku peduli". Kepedulian tersebut memiliki makna bahwa BJB Syariah berusaha untuk mengerti apa yang menjadi kebutuhan nasabah, dan merespon complain dari nasabah serta memberikan solusi terbaik untuk mengatasinya. Pemberian solusi terhadap permasalah nasabah yang terdapat dalam moto pelayanan I Care dijabarkan ke dalam beberapa poin sebagai berikut (BJB : Syariah) :
1) In Tune Listening = mendengarkan nasabah dengan seksama. In Tune Listening merupakan tahap dimana karyawan bank harus mendengarkan complain nasabah dengan penuh perhatian. Complain nasabah pada bank biasanya diterima untuk pertamakalinya oleh costumer service. Setelah mendengarkan complain nasabah, costumer service harus meminta maaf atas ketidakpuasan nasabah terhadap pelayanan yang diberikan oleh bank.

2) Confirmation = konfirmasi. Tahap ini merupakan tahap dimana bank menelaah apa yang menjadi keluhan nasabah. Keluhan tersebut kemudian dicarikan alternatif solusinya. Pihak bank harus memberikan penjelasan mengenai pilihan solusi yang dapat digunakan oleh nasabah. Terakhir, bank memastikan pilihan solusi nasabah bahwa solusi tersebut merupakan solusi terbaik yang diinginkan oleh nasabah.

3) Action = tindakan. Tahap ini merupakan tindakan proses penyelesaian keluhan nasabah. Proses penyelesaian harus diselesaikan sesegera mungkin oleh pihak bank. Complain yang diberikan nasabah kepada costumer service harus dilanjutkan kepada pihak yang berhak dan ahli dalam menyelesaikannya.

4) Recovery = pemulihan. Tahap ini merupakan tahapan terakhir dari konsep pelayanan di BJB Syariah. Pemulihan memiliki pengertian tindak lanjut atas permasalahan yang terjadi. Tindak lanjut tersebut dapat berupa pembaharuan aturan baru pelayanan yang dapat meminimalisir complain dari nasabah.

\section{Konsep Dasar Pelayanan Menurut Al-Qur'an}

Pelayanan merupakan hal yang sangat penting dalam dunia perbankan, hal ini disebabkan karena usaha perbankan memiliki hubungan 
yang sangat erat dengan pihak lain (nasabah). Tanpa nasabah usaha perbankan tidak akan berjalan dengan baik, sehingga hubungan dengan nasabah harus dijaga dengan baik. Dalam menjalin hubungan dengan nasabah ada tiga konsep dasar pelayanan yang perlu diperhatikan oleh bank syariah yaitu keikhlasan, kesuaian pelayanan dengan syariat, dan berusaha melayani dengan pelayanan terbaik.

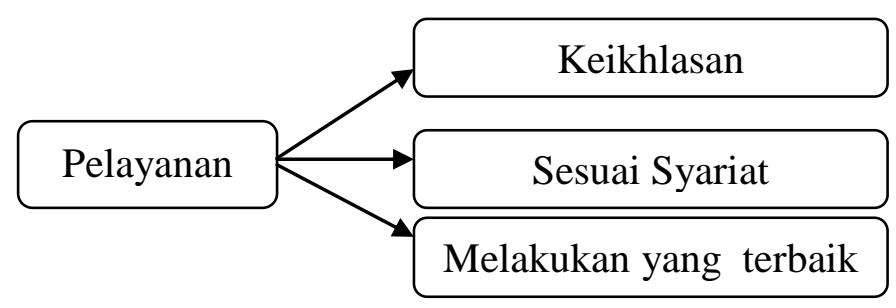

Gambar 1

Konsep Dasar Pelayanan Menurut Al-Qur'an

Sumber : Data diolah dari berbagai sumber (2014)

\section{a. Keikhlasan}

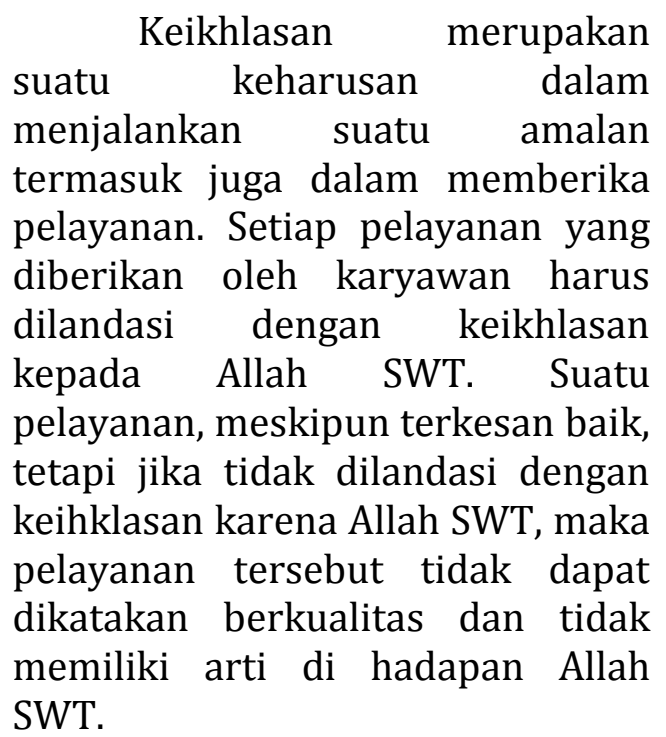

Rasulullah menjelaskan hal ini dalam sabdanya : "Dari $A b u$ Qatadah RA, dari Rasulullah SAW, beliau berada di antara para sahabat seraya berkata, 'Sesungguhnya berjuang atau berjihad di jalan Allah dan beriman kepada-Nya adalah sebaik-baik perbuatan." Tiba-tiba seorang lelaki berdiri dan bertanya kepada beliau, "Ya Rasulullah, bagaimana menurut pendapat engkau jika saya terbunuh di jalan Allah, apakah semua dosa saya akan diampuni?" Rasulullah menjawab, "Benar. Apabila kamu terbunuh di jalan Allah dalam kondisi yang sabar dan ikhlas karena-Nya, maka semua dosamu akan diampuni." Lalu Rasulullah SAW bertanya, "Apa pertanyaanmu tadi?' Laki-laki itu mengulangi pertanyaannya, "Ya Rasulullah, bagaimana menurut pendapat engkau jika saya terbunuh di jalan Allah, apakah semua dosa saya akan diampuni?" Rasulullah menjawab, "Benar. Itupun kalau kamu dalam kondisi yang sabar dan ikhlas karena Allah, maka semua dosamu akan diampuni, kecuali utang. Itulah yang disampaikan Jibril kepadaku." ( HR. Muslim).

b. Sesuai dengan Syariat

Pelayanan yang diberikan kepada nasabah harus sesuai dengan syariat. Syariat dapat diartikan aturan Allah SWT yang mengatur seluruh sendi kehidupan umat manusia. Syariat tidak hanya berisi panduan mengenai masalah ibadah, tetapi merupakan panduan yang menyeluruh mengenai permasalahan kehidupan manusia. Kesyariahan harus dijunjung tinggi dan diterapkan dalam segala aspek kehidupan termasuk ketika memberikan pelayanan kepada nasabah.

Hal terpenting yang perlu diperhatikan dalam penerapan pelayanan di perbankan syariah yaitu bank syariah harus memastikan bahwa produk perbankan yang dijual adalah produk yang halal. Bank-bank syariah yang ada saat ini telah berupaya memastikan kehalalan 
produk perbankan yang dijual dengan menetapkan Dewan Pengawas Syariah. Dewan Pengawasan Syariah inilah yang kemudian akan memeriksa dan menjamin kehalalan produk bank syariah dengan pertimbangan fatwa yang dikeluarkan oleh Dewan Syariah Nasional (DSN) MUI. Selain memastikan kehalalan produknya, ada beberapa prinsip syariah pelayanan yang harus diperhatikan oleh bank syariah, yaitu (Mukinim : 2011) :
1) Prinsip persamaan (Al- Musawah) yaitu tidak membedakan pelayanan terhadap nasabah (surat Al- Hujarat ayat 13).
2) Prinsip persaudaraan (Ukhuwah) yaitu penyelesaian masalah harus diselesaikan dengan prinsip kekeluargaan (surat Al-Hujarat ayat 10).

3) Prinsip cinta kasih (Muhabbah) ; bentuk prinsip ini dalam pelayanan misalnya tidak saling menyalahkan ketika ada complain dari nasabah. (surat Al-Balad 177).

4) Prinsip perdamaian (Silm) misalnya penyelesaian masalah dengan cara non litigasi seperti Badan Arbitrase Syariah Nasional (Basyarnas) (surat Alanfal ayat 61).

5) Prinsip tolong-menolong (Atta'awun) yaitu menolong kesusahan nasabah (surat Almaidah ayat 1 ).

\section{c. Melakukan yang terbaik.}

Kesungguhan dalam
beramal merupakan bukti
keikhlasan seseorang. Perbuatan
yang dilakukan tanpa kesungguhan
dapat dikatakan sebagai amal yang
tidak dilandasi dengan keikhlasan,

karena keikhlasan cenderung akan mendorong seseorang untuk melakukan yang terbaik. Allah SWT berfirman :

"Hai manusia, Sesungguhnya kamu telah bekerja dengan sungguhsungguh menuju Tuhanmu, Maka pasti kamu akan menemui-Nya"(AlInsyiqaq ayat 6)

Ayat ini menjelaskan bagaiman manusia akan menempuh perjalanan hidup. Manusia harus bekerja keras, memikul beban hidup dan serta mencurahkan segenap tenaga untuk mencapai kesenangan. Tanpa kerja keras dan kesungguhan maka mustahil bagi manusia akan mendapatkan kesenangan ( Qutub : 2008). Itulah sebabnya mengapa setiap pekerjaan harus dilakukan dengan totalitas. Begitu juga dalam memberikan pelayanan, karyawan bank syariah harus memberikan pelayanan dengan totalitas. Totalitas berarti karyawan bukan hanya memberikan pelayanan sesuai SOP yang ditetapkan oleh Bank, tetapi lebih dari itu mereka harus memberikan kemampuan yang terbaik dan sepenuh hati dalam melayani. Para karyawan harus berusaha memberikan nilai tambah perusahaan, memperhatikan suasana hati nasabah, dan secara konsisten memperhatikan sikap, perilaku, dan karakter yang membuat pelanggan bahagia dan tercukupi.

Totalitas dalam memberikan pelayanan merupakan suatu keharusan bagi karyawan. Hal ini memiliki hubungan yang sangat erat dengan firman Allah SWT pada surat Al-Baqarah ayat 208 yang memerintahkan kita untuk masuk islam dengan totalitas, yaitu : 
"Hai orang-orang yang beriman, masuklah kamu ke dalam Islam keseluruhan, dan janganlah kamu turut langkah-langkah syaitan. Sesungguhnya syaitan itu musuh

(totalitas). Ketika seseorang telah mengaku Islam maka dia memiliki diwajibkan untuk melaksanakan semua yang diperintahkan islam dengan totalitas ( Zuhaily : 2003). Secara keseluruhan ini memiliki makna bahwa kita harus mengamalkan Islam dengan mengerahkan segenap kemampuan yang dimiliki (Al-Imam Abu Fida Proses pelayanan bank syariah kepada nasabah sangat mirip dengan proses dakwah seorang da'i kepada objek dakwahnya. Setiap da'i dalam berdakwah dituntut untuk memperbaiki diri sendiri, sebelum menyampaikan dakwah kepada orang lain. Alangkah tidak pantasnya seorang da'i yang berdakwah sedangkan ia lupa terhadap diri sendiri. Allah SWT mengingatkan tentang hal ini di dalam surat Al-Baqarah ayat 44, yaitu :

"Mengapa kamu suruh orang lain (mengerjakan) kebaktian, sedang kamu melupakan diri (kewajiban) mu sendiri, Padahal kamu membaca Al kitab (Taurat)? Maka tidaklah kamu berpikir?

Latar belakang turunnya ayat ini menurut Ibnu Abbas adalah diantara orang Yahudi Madinah ada yang member nasihat kepada keluarganya yang sudah masuk Islam untuk tetap memeluk Islam. Apa yang diperintahkan orang Yahudi ini adalah menyaksikan perbuatan yang buruk ( Qutub : 2008). Itulah sebabnya mengapa setiap individu atau kelompok harus memperhatikan keadaannya sendiri dan menjauhi sifat yang terdapat dalam ayat tersebut. Ibrah yang dapat diambil dari ayat diatas dalam implementasi pelayanan yang nyata bagimu. (Al-Baqarah ayat 208)

Ayat ini menerangkan bahwa Allah SWT menyeru kepada orang beriman untuk masuk kedalam Islam secara keseluruhan (Ibnu Katsi : 2000). Begitu juga dengan pelayanan di bank syariah harus dilaksanakan dengan mengerahkan kemampuan terbaik agar mendapatkan hasil yang maksimal.

\section{Proses Pelayanan Bank Syariah Berdasarkan Al-Qur'an}

benar yaitu menyuruh orang lain untuk berbuat benar tetapi mereka sendiri tidak mengamalkannya. Allah SWT mencela tingkah laku dan perbuatan mereka, yang melupakan diri mereka sendiri. Allah SWT bahkan memandang mereka seolah-olah tidak mempunyai akal, sebab orang berakal betapapun lemahnya tentu akan mengamalkan ilmunya (Departemen Agama RI : 2009).

Firman Allah ini merupakan nash ditujukan kepada Bani Israil, walaupun demikian Nash ini juga ditujukan kepada seluruh manusia. Tindakan dakwah yang berbeda dengan apa yang disampaikan akan merupakan suatu bencana yang akan menimbulkan keraguan dalam jiwa. Hal ini bukan hanya membahayakan pendakwah saja, tetapi juga membahayakan dakwah itu sendiri. Pasalnya, orang yang didakwahi menjadi bingung karena mereka mendengarkan perkataan yang bagus, tetapi bank syariah adalah bank syariah hendaknya memperhatikan keadaan diri sendiri terlebih dahulu sebelum memberikan pelayanan kepada nasabah. Hal ini memiliki pengertian bahwa bank syariah harus memenuhi apa yang menjadi kebutuhan karyawan. Pemenuhan kebutuhan 
karyawan dapat dilakukan dengan cara memberikan jaminan kesejahteraan, jaminan kesehatan, dan pelatihan-

Pemenuhan kebutuhan jaminan kesejahteraan misalnya BTN syariah yang memberikan gaji pokok setiap bulan, bonus lembur dan sebagainya (BTN Syariah:2014). Jaminan kesehatan seperti yang dilakukan oleh BJB Syariah yaitu berupa tanggungan biaya berobat, layanan rawat inap, melahirkan, penyediaan dokter spesialis untuk pegawai tetap, sedangkan untuk outsourching BJB Syariah menyediakan asuransi kesehatan. Sementara untuk pelatihanpelatihan karyawan biasa dilakukan BJB Syariah enam bulan sekali (Karina:2014).

\section{Pelayanan Terhadap Nasabah Berdasarkan Al-Qur'an}

Kondisi perbankan syariah saat ini bisa dikatakan hampir sama dengan kondisi dakwah Rasulullah SAW. pelatihan yang dilaksanakan untuk upgrading kemampuan karyawan.

Dakwah Rasulullah SAW begitu terjal, dipenuhi dengan banyak cobaan dan rintangan, tetapi akhirnya dakwah beliau berhasil. Keberhasilan dakwah Rasulullah SAW tersebut tidak lepas dari kepiawaian beliau berdakwah yaitu dalam memikat dan menjalin hubungan dengan objek dakwah. Metode Rasul dalam memikat dan menjalin hubungan dengan objek dakwah dapat menjadi acuan bagi Perbankan Syariah dalam memberikan Pelayanan sehingga Nasabah akan terpikat dan menjadi loyal kepada Bank Syariah. Al-Qur'an sendiri mengabadikan bagaimana cara beliau memikat dan menjalin hubungan dengan objek dakwah dalam banyak ayat dalam Al-Qur'an diantaranya surat Al-Ahzab ayat 21, surat Ali Imran ayat 159 , surat An-Nahl ayat 125 , dan surat Al-Muddatstsir ayat 1-7

Tabel 1 Pelayanan Terhadap Nasabah Berdasarkan Al-Qur'an

\begin{tabular}{|c|c|c|}
\hline No & Surat dan ayat & Ibrah dalam Pelayanan Bank Syariah \\
\hline 1 & Al-Ahzab ayat 21 & $\begin{array}{l}\text { - Mencontoh Rasulullah SAW dalam } \\
\text { melayani nasabah seperti jujur, ikhlas, } \\
\text { memberi kemudahan ketika transaksi, } \\
\text { professional dan menjalin hubungan } \\
\text { baik dengan nasabah }\end{array}$ \\
\hline 2 & $\begin{array}{l}\text { Ali Imran ayat } \\
159\end{array}$ & $\begin{array}{l}\text { - Melayani nasabah dengan lemah } \\
\text { lembut } \\
\text { - Karyawan harus memiliki sifat pemaaf } \\
\text { - Menyelesaikan masalah dengan } \\
\text { musyawarah } \\
\text { - } \text { kebulatan tekad dalam melayani } \\
\text { Tawakkal terhadap hasil pelayanan }\end{array}$ \\
\hline 3 & An-Nahl 125 & $\begin{array}{l}\text { - Menarik minat dan menjalin hubungan } \\
\text { dengan nasabah dengan metode } \\
\text { dakwah Rasulullah SAW yaitu : Al- } \\
\text { Hikmah, Al-Mau'idzoh bil Hasanah, Al- } \\
\text { mujadalah bil Hasanah. }\end{array}$ \\
\hline 4 & $\begin{array}{l}\text { Al-Muddatstsir } \\
\text { ayat 1-7 }\end{array}$ & $\begin{array}{l}\text { - Menyapa nasabah dengan baik } \\
\text { - Rajin, ulet, dan cepat dalam melayani }\end{array}$ \\
\hline
\end{tabular}


nasabah

- Mendahulukan kepentingan Allah dibandingkan nasabah

- Menjaga penampilan dan kebersihan

- Melayani sesuai dengan syariat

- Keikhlasan dalam melayani

- Kesabaran dalam melayani

Sumber : Hasil penelitian (Data diolah dari berbagai sumber : 2014)

\section{a. Surat Al-Ahzab ayat}

" Sesungguhnya telah ada pada (diri) Rasulullah itu suri teladan yang baik bagimu (yaitu) bagi orang yang mengharap (rahmat) Allah dan (kedatangan) hari kiamat dan Dia banyak menyebut Allah" (Al-Ahzab ayat 21).

Surat Al-Ahzab ayat 21 ini adalah ayat yang turun pada saat terjadinya peristiwa ahzab (perang khandak) ( Qutub : 2004). Ayat ini merupakan gambaran perilaku agung Rasulullah SAW dalam perkataan, perbuatan dan perilakunya. Untuk itu, Allah SWT memerintahkan kita untuk meneladani akhlak dan sifat Rasulullah SAW dalam semua tindakannya (Abdullah :2004).

Rasulullah SAW adalah seorang yang sabar, berani, tabah dalam menghadapi cobaan, dan mempunyai akhlak yang mulia. Jika kita ingin menjadi manusia yang baik, dan bahagia hidup di dunia dan di akhirat maka kita harus meneladani Rasulullah SAW (Depag RI :2009).

Hikmah atau pelajaran yang terdapat pada surat Al-Ahzab ayat 21 dalam hal penerapan pelayanan pada bank syariah yaitu karyawan bank harus mencontoh akhlak Rasulullah SAW dalam setiap perilaku. Akhlak baik karyawan hendaknya tidak hanya ditunjukkan pada saat melayani para pelanggan saja, tetapi akhlak baik tersebut merupakan bagian yang tetap melekat pada diri karyawan. Karyawan hendak tetap menjaga akhlak baik ketika di luar kerja, lebih-lebih pada saat jam kerja. Hal ini disebabkan karena saat ini pelanggan telah menjadi sangat sensitive, satu hal kecil yang menjadi kesalahan akan mengakibatkan reaksi yang dapat mengakibatkan pada hancurmya kredibilitas perusahaan ( Gunawa : 2007).

Rasulullah SAW yang merupakan seorang pedagang, banyak mencontohkan bagaimana beliau melayani pelanggan dalam transaksi perdagangan. Pelayanan merupakan suatu yang sangat beliau perhatikan dalam transaksi perdagangan. Bentuk pelayanan yang diajarkan Rasulullah SAW sangat patut untuk diimplementasikan oleh karyawan bank syariah dalam memberikan pelayanannya. Bentuk pelayanan yang diajarkan Rasulullah SAW ini tidak hanya mampu menciptakan pelanggan yang loyal (costumer loyality) tetapi juga membuat pelanggan percaya (trusty costumer). Trusty costumer ini terbentuk karena Rasulullah SAW memberikan nilai tambah (value added) dan pengalaman berbelanja (experiential marketing) dalam memberikan pelayanan kepada nasabah. Value added dan experiential marketing dilakukan dengan menerapkan formula 
kejujuran, keikhlasan, profesionalisme, silaturrahmi, dan bermurah hati. Kelima formula inilah yang menjadi inti dari marketing dan pelayanan yang diberikan oleh Rasulullah SAW kepada para pelangganya.

\section{b. Surat Ali Imran Ayat 159}

Artinya : "Maka disebabkan rahmat dari Allah-lah kamu Berlaku lemah lembutlah terhadap mereka. Sekiranya kamu bersikap keras lagi berhati kasar, tentulah mereka menjauhkan diri dari sekelilingmu. karena itu ma'afkanlah mereka, mohonkanlah ampun bagi mereka, dan bermusyawaratlah dengan mereka dalam urusan itu. kemudian apabila kamu telah membulatkan tekad, Maka bertawakkallah kepada Allah. Sesungguhnya Allah menyukai orang-orang yang bertawakkal kepada-Nya"

Ibrah yang dapat diambil dari surat Ali Imran ayat 159 berkaitan dengan penerapan pelayanan pada bank syariah diantaranya :

1) Karyawan harus memiki sifat lemah lembut dalam melayani nasabah. konsep kelembutan sangat cocok diterapkan dalam pelayanan bank syariah. konsep ini telah dibuktikan oleh Rasulullah dalam dakwahnya. Inilah metode marketing handal (dakwah) yang diterapkan Rasulullah SAW yang menjadikan Madinah dan Habsyi menjadi tempat kondusif untuk umat islam, padahal yang memasukkan dakwah islam pertama kali kesana adalah para sahabat, bukan Rasulullah. Akan tetapi Para sahabat ini dibekali ilmu pelayanan oleh Rasulullah SAW sehingga menjadi da'i yang unggul (Sulfiantono : 2006).

2) Karyawan harus menerapkan sifat pemaaf yang diajarkan oleh Rasulullah SAW. Penerapan sifat pemaaf ini dalam pelayanan perbankan syariah misalnya costumer service harus memaklumi nasabah yang marah-marah ketika melakukan complain. Profesi costumer service sebagai profesi yang paling sering berhadapan langsung dengan konsumen dituntut memiliki sifat pemaaf dan tetap melayani konsumen dengan baik. Selain itu, costumer service juga diharuskan untuk memiliki Ketahanan mental yang kuat, mampu bersabar dan menahan amarah. Ketiga hal tersebut merupakan modal dasar yang sekurang-kurangnya wajib dimiliki oleh mereka sehingga para konsumen akan merasa puas dengan pelayanan yang diberikan oleh bank syariah.

3) Setiap permasalahan dengan nasabah harus diselesaikan dengan musyawarah, karena musyawarah akan menghindarkan pertikaian antara pihak bank dan nasabah.

4) Karyawan harus tawakkal terhadap hasil pelayanan. Karyawan hanya berkewajiban memberikan pelayanan yang terbaik, sedangkan hasil dari pelayanan tersebut hanya Allahlah yang menentukan. Ketawakkalan tersebut dapat diwujudkan melalui berdo'a kepada Allah SWT agar costumer yang dilayani menjadi loyal dan memberikan banyak manfaat bagi bank syariah. 


\section{c. Surat An-Nahl Ayat 125}

"Serulah (manusia) kepada jalan Tuhan-mu dengan Al-Hikmah dan pelajaran yang baik dan bantahlah mereka dengan cara yang baik. Sesungguhnya Tuhanmu Dialah yang lebih mengetahui tentang siapa yang tersesat dari jalan-Nya dan Dialah yang lebih mengetahui orang-orang yang mendapat petunjuk".

Ibrah yang dapat diambil dari surat An-Nahl ayat 125 yaitu bank syariah harus menerapkan metode dakwah Rasulullah dalam menarik dan menjalin hubungan dengan nasabah. Metode dakwah tersebut yaitu Al-Hikmah, AlMau'idzoh bil Hasanah, AlMujadalah bil Hasanah.

1) Al-Hikmah yaitu menyesuaikan dakwah sesuai dengan karakter, sifat dan tingkat pemahaman objek dakwah (Abdurrahman As-Sya'diy. Hal ini memiliki pengertian bahwa bank syariah harus mampu menerapkan strategi pemasaran yang sesuai dengan keberagaman nasabah. Keberagaman tersebut misalnya nasabah pelajar (mahasiswa), pengusaha, karyawan, nasabah Non-Muslim dan sebagainya. Bank syariah dalam hal ini dapat membuat program marketing (produk, harga, pelayanan) yang sesuai dengan keberagaman nasabah tersebut. Rasulullah SAW bersabda "perlakukanlah seseorang itu sesuai keadaannya masingmasing dan berkomunikasilah sesuai dengan kemampuan nalarnya" (Hasan : 2011)

2) Al-Mau'idzoh bil Hasanah memiliki pengertian nasehat yang baik. Penerapan konsep Al-Mau'idzoh bil Hasabah sangat sesuai untuk diterapkan pada nasabah yang baru mengenal perbankan. Penerapan tersebut dapat berupa pembinaan dan pendampingan nasabah, pelatihan pembuatan laporan keuangan dan sebagainya sehingga bank syariah dapat memberikan rasa nyaman kepada nasabah yang baru berinteraksi dengan bank.

3) Al-Mujadalah bil Hasanah berarti berdebat dengan cara yang baik. penerapan metode ini sangat diperlukan terutama ketika mensosialisasikan produk perbankan kepada nasabah. Para karyawan bank syariah harus mampu menjelaskan kelebihan produk bank syariah dibanding dengan produk konvensional. Penjelasan tersebut bukan hanya mengedepankan haram dan halalnya produk, tetapi juga penjelasan keunggulan produk perbankan syariah dibandingkan konvensional melalui retorika dan alasan ilmiah lainnya. Itulah mengapa perbankan syariah harus memiliki karyawan dengan keilmuan yang mumpuni, sehingga dapat menjelaskan dengan detail dan jelas keunggulan dan kelebihan produk perbankan syariah.

\section{d. Surat Al-Muddatstsir ayat}

"Hai orang yang berkemul (berselimut) (1) bangunlah, lalu berilah peringatan! (2) dan Tuhanmu agungkanlah! (3) dan pakaianmu bersihkanlah, (4) dan perbuatan dosa tinggalkanlah, (5) dan janganlah kamu memberi (dengan maksud) memperoleh (balasan) yang lebih banyak. (6) 
dan untuk (memenuhi perintah)

Tuhanmu, bersabarlah (7)".

Ada beberapa ibrah/pelajaran yang dapat diambil dari surat AlMuddatstsir ayat 1-7 dalam penerapan pelayanan bank syariah diantaranya yaitu :

1) Menyambut nasabah dengan baik sebagaimana dicontohkan dalam surat Al-Muddatstsir ayat 1 yaitu Sapaan "wahai orang yang berselimut". Sapaan "wahai orang

berselimut"merupakan

panggilan sayang, karena dalam sastra arab salah satu panggilan sayang ditandai dengan bahasa yang menggambarkan keadaan seseorang dengan keadaan saat di panggil (Depag RI : 2009).

2) Kecepatan dalam melayani serta rajin, ulet dan tidak putus asa. Hal ini ditunjukkan oleh kat "Qum"pada ayat 2 surat AlMuddatstsir.

3) Mengutamakan kepentingan Allah dibandingkan kepentingan lainnya, misalnya tidak menunda melaksanakan shalat hanya karena melayani nasabah.

4) Menjaga penampilan dan kebersihan pakaian sebagaimana yang tercantum dalam ayat 4 yang berarti : "dan pakaianmu bersihkanlah”.

5) Tindakan karyawan bank syariah dalam memberikan pelayanan harus terhindar dari segala hal yang mendatangkan siksaan dari Allah SWT. Hal ini memiliki arti bahwa tindakan pelayanan harus disesuaikan dengan ketentuan syariah seperti jujur dalam menjelaskan kelebihan dan keterbatasan yang dimiliki produk, karena pada hakikatnya aktivitas menjual produk tidak hanya bertujuan semata-mata agar nasabah membeli produk, tetapi lebih dari itu kita menjual nilainilai islam kepada mereka (surat Al-Muddatstsir ayat 5).

6) Pelayanan yang diberikan hendaknya selalu dilandasi keikhlasan dengan niat bahwa pelayanan adalah sarana menolong sesama (nasabah). Artinya karyawan memberikan pelayanan tidak hanya berorientasi materi (gaji) melainkan juga harus memperhatikan aspek ibadah dari pelayanan yang diberikan. (surat Al-Muddatstsir ayat 6).

7) Karyawan harus memiliki kesabaran dalam melayani nasabah. Karyawan terutama Costumer Service akan sangat membutuhkan kesabaran dalam melayani, karena mereka akan menghadapi berbagai macam tipikal nasabah. Dengan demikian kita dapat menyimpulkan bahwa kesabaran merupakan modal utama yang harus dimiliki karyawan dalam memberikan pelayanan kepada nasabah.

Berdasarkan penjelasan ayat-ayat Al-Qur'an mengenai konsep service excellence perbankan syariah dapat disimpulkan bahwa konsep service excellence tersebut merupakan kombinasi aspek aqidah, akhlak dan muamalah (Finalist $1^{\text {st }}$ IsEFEF : 2012). Aqidah dapat diartikan sebagai visi dan makna bagi eksistensi kehidupan manusia dalam kehidupan. Aqidah akan memberikan arah kehidupan serta kemana semuanya akan berakhir ( Karim : 2004). Hal ini memiliki pengertian bahwa segala aktivitas manusia harus dilandasi dengan niat ibadah kepada Allah SWT. Begitu juga dengan pelayanan yang diberikan kepada nasabah harus dijadikan 
sebagai sarana beribadah kepada Allah SWT.

Aspek akhlak merupakan buah dari pemahaman terhadap aqidah. Akhlak dalam islam biasa dikenal dengan istilah ihsan. Ihsan memiliki pengertian bahwa kita selalu merasa diawasi oleh Allah SWT yang mengetahui, melihat, dan mendengar sekecil apapun perbuatan yang kita lakukan. Dengan kesadaran ini, tentunya akan membuat seseorang terdorong untuk berperilaku baik dan menjauhi perilaku buruk (Nurhayati : 2009). Konsep akhlak ini juga memiliki kaitan yang sangat erat dengan konsep pelayanan perbankan syariah yang terdapat dalam Al-Qur'an yaitu bahwa hendaknya pelayanan harus dilandasi pada nilai-nilai akhlak yang diajarkan oleh Rasulullah SAW.

Selanjutnya, aspek muamalah yaitu aspek yang mengatur interaksi atau hubungan antara sesama manusia. Aturan tersebut mencakup semua aspek hidup manusia mulai dari pernikahan, sosial, ekonomi, politik dan sebagainya. Cakupan aturan hubungan antar sesama manusia tersebut memiliki tujuan untuk kebaikan dan kemaslahatan manusia baik di dunia maupun akhirat.

Tabel 2 Aspek Aqidah, Akhlak dan Muamalah Konsep Service Excellence Perbankan Syariah Berdasarkan Al-Qur'an

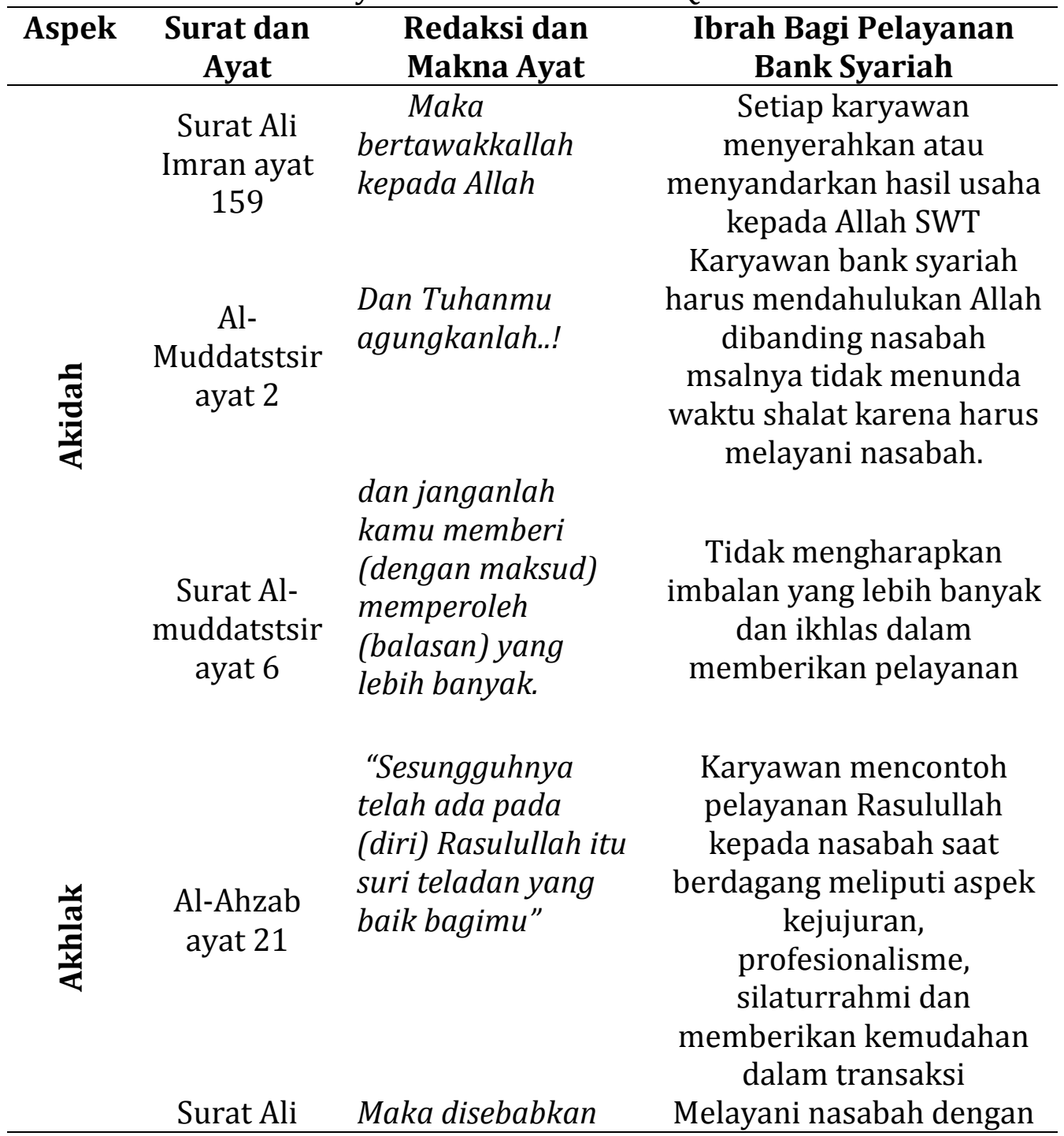




$\begin{array}{cl}\text { Imran } 159 & \begin{array}{l}\text { rahmat dari Allah- } \\ \text { lah kamu Berlaku } \\ \text { lemah lembut } \\ \text { terhadap mereka. }\end{array} \\ & \\ & \begin{array}{l}\text { dan perbuatan dosa } \\ \text { tinggalkanlah, }\end{array} \\ \text { Surat Al- } & \text { Muddatstsir } \\ \text { ayat 5 } & \end{array}$

$\begin{array}{clrl} & \text { karena } & \text { itu } & \begin{array}{l}\text { Costumer service harus } \\ \text { memiliki sifat pemaaf }\end{array} \\ \text { Surat Ali } & \text { ma'afkanlah } & & \text { sehingga dapat } \\ \text { Imran ayat } & \begin{array}{l}\text { mereka, } \\ \text { mohonkanlah } \\ \text { ampun } \\ \text { mereka, }\end{array} & \text { bagi } & \text { memaklumi nasabah yang } \\ & & \end{array}$

Surat Ali Imran ayat 159 lemah lembut.

Tindakan karyawan bank syariah harus sesuai dengan syariah karena keryawan tidak hanya menjual produk melainkan juga menjual nilai-nilai islami kepada nasabah.

Setiap permasalahan yang terjadi antara bank syariah dan nasabah hendaknya diselesaikan dengan musyawarah.

Karyawan menggunakan metode hikmah, almaui'dzoh bil hsanah dan al-mujadalah bil hasanah dalam melakukan pendekatan kepada nasabah

\section{Memberikan pelayanan dengan kesungguhan (kebulatan tekad)}

Menyeru/memulai sapaan kepada nasabah dengan sapaan yang baik.

Bersegera dalam melayanai (Memberikan kecepatan) dalam melayani serta rajin, dan ulet.

Menjaga penampilan dan kebersihan ketika melayani 


\begin{tabular}{clc} 
Surat Al- & $\begin{array}{l}\text { dan untuk } \\
\text { (memenuhi }\end{array}$ & $\begin{array}{c}\text { Bersabar karena Allah } \\
\text { dalam melayani dan }\end{array}$ \\
Muddatstsir & $\begin{array}{l}\text { perintah) Tuhanmu, } \\
\text { ayat 7 }\end{array}$ & menghadapi nasabah. \\
\hline
\end{tabular}

Sumber : Hasil penelitian (Data Diolah dari berbagai sumber : 2014)

\section{Relevansi Konsep Service Excellence Perbankan Syariah dengan Konsep Service Excellence Berdasarkan Al- Qur'an.}

Konsep pelayanan bank syariah saat ini memiliki hubungan yang sangat erat dengan konsep pelayanan yang ada di dalam Al-Qur'an. Bank syariah dalam melayani nasabah telah menerapkan banyak konsep pelayanan yang terdapat dalam Al-Qur'an. Di antara konsep pelayanan Al-Qur'an yang diterapkan dalam pelayanan bank syariah yaitu kesabaran dalam melayani nasabah, menyapa nasabah dengan baik, berusaha memberikan pelayanan yang terbaik, bersikap lemah-lembut, memberikan kecepatan dalam melayani, dan sebagainya. Namun demikian, ada beberapa hal yang harus diperhatikan oleh bank syariah dalam memberikan pelayanan kepada nasabah yaitu :

a. Bank syariah harus menerapkan prinsip Al-Musawah (persamaan) dalam memberikan pelayanan kepada nasabah. Hal ini menunjukkan bahwa bank syariah tidak diperkenankan untuk mengklasifikasikan nasabah menjadi nasabah prima dan nasabah biasa. Bank-bank Syariah di Indonesia saat ini masih melakukan penerapan yang berbeda mengenai pembedaan nasabah prima dan nasabah biasa. Dari hasil penelitian di BJB Syariah dan BTN Syariah dapat disimpulkan bahwa kedua Bank tersebut menerapkan pemberlakuan yang berbeda kepada nasabah. BJB Syariah menyatakan bahwa mereka tidak membedakan antara nasabah prima dan nasabah biasa (Karina : 2014). Sementara itu, BTN Syariah memberikan perlakuan yang berbeda antara nasabah prima dan nasabah biasa.

Pengklasifikasian dan Pembedaan pelayanan terhadap nasabah perlu ditelaah kembali kesyariahannya, karena hal ini tidak sesuai dengan nilai-nilai yang terkandung dalam Al-Qur'an. Allah SWT berfirman :

"Hai manusia, Sesungguhnya Kami menciptakan kamu dari seorang laki-laki dan seorang perempuan dan menjadikan kamu berbangsa bangsa dan bersuku-suku supaya kamu saling kenal-mengenal. Sesungguhnya orang yang paling mulia diantara kamu disisi Allah ialah orang yang paling taqwa diantara kamu. Sesungguhnya Allah Maha mengetahui lagi Maha Mengenal" (Al-hujarat : ayat 13) Dalam ayat ini disebutkan bahwa yang membedakan kemuliaan seorang hamba dengan hamba lainnya di hadapan Allah SWT adalah ketaqwaannya. Hal inilah yang seharusnya menjadi landasan bank syariah dalam memberikan pelayanan. Bank syariah tidak boleh mengklasifikan dan membedakan pelayanan kepada nasabah prima dan nasabah biasa, karena hal ini akan membuat seolah-olah orang kaya lebih mulia daripada orang miskin. Akan tetapi bank syariah bisa saja memberikan pelayanan lebih kepada deposan 
besar sebagai tanda terimakasih atas kontribusinya terhadap kemajuan usaha bank, asalkan hal tersebut tidak dilakukan dengan berlebihan seperti memotong antrian nasabah lain, meninggalkan pelayanan nasabah biasa disaat nasabah prima datang dan sebagainya.

Selain itu, upaya bank untuk memenuhi kebutuhan nasabah prima juga berpotensi meningkatkan profil risiko perbankan, khususnya risiko operasional, risiko hukum, dan risiko reputasi. Sehubungan dengan hal tersebut, Bank Indonesia menerapkan manajemen risiko melalui peraturan tentang layanan nasabah prima. Peraturan ini terkait dengan anti pencucian uang dan pencegahan pendanaan teroris, transparansi informasi produk bank dan penggunaan data pribadi nasabah sebagai acuan standar minimal bagi bank dalam memberikan layanan kepada nasabahnya (bi.go.id).

b. Setiap pelayanan karyawan bank syariah yang diberikan kepada nasabah harus dilandasi keikhlasan kepada Allah SWT. Keikhlasan harus terus dipupuk oleh setiap karyawan bank syariah, kerena keikhlasan merupakan syarat diterimanya amal seseorang. Layanan bank syariah yang terkesan baik akan menjadi sia-sia dan tidak akan bernilai dihadapan Allah SWT apabila tidak didasari dengan keikhlasan kepada-Nya.

\section{Implementasi Konsep Service Excellence Al-Qur'an pada Perbankan Syariah}

Impelementasi nilai-nilai konsep service excellence Al-Qur'an perbankan syariah merupakan konsep yang tertuju pada nilai aqidah, yaitu bahwa setiap pelayanan yang diberikan harus dilandasi keikhlasan kepada Allah SWT. Keikhlasan harus terus dilatih agar pelayanan bernilai ibadah di hadapan Allah SWT. Dari penelitian yang dilaksanakan di BTN Syariah dan BJB Syariah penerapan nilai aqidah (keikhlasan) ini telah dilakukan dengan cara melakukan kegiatan do'a bersama sebelum kegiatan operasional dimulai. Berdo'a bersama merupakan salah satu cara untuk melatih keikhlasan, walaupun pada hakikatnya keikhlasan tidak dapat dinilai dengan kasat mata dan hanya Allah yang mengetahui keikhlasan seseorang. Selain penerapan nilai aqidah ada banyak penerapan nilai-nilai konsep service excellence Al-Qur'an dalam pelayanan yang diberikan bank syariah kepada nasabah, diantaranya :

a. Perbankan Syariah berusaha memastikan bahwa produk perbankan yang dijual adalah produk yang halal. Hal ini diupayakan melalui Dewan Pengawas Syariah (DPS) yang akan mengawasi apakah produk yang dijual merupakan produk yang halal dan sesuai dengan syariah.

b. Perbankan syariah berusaha memberikan pelayanan yang sesuai dengan syariat misalnya menyambut nasabah dengan salam, adanya SOP yang melarang bersentuhan tangan dengan nasabah yang bukan muhrim dan sebagainya (BTN Syariah : 2014). Akan tetapi bank syariah dalam upayanya memberikan pelayanan yang sesuai dengan syariah terdapat ketidaksesuaian pelayanan dengan syariat misalnya masih adanya bank syariah yang menerapkan perbedaan perlakuan kepada nasabah prima dan nasabah biasa. Perbedaan perlakuan terhadap nasabah ini tidak sesuai dengan konsep Al-Musawah 
(persamaan) yang terdapat pada surat Al-Hujarat ayat 13 .

c. Perbankan syariah telah menerapkan banyak nilai-nilai konsep service excellence yang terdapat dalam Al-Qur'an seperti bersikap lemah-lembut kepada nasabah, ramah dalam menyambut nasabah, sabar dalam melayani dan menghadapi complain nasabah dan sebagainya. Penerapan nilai-nilai konsep service excellence tersebut dapat dilihat dari Standard Operating Prosedure (SOP) pelayanan yang bersesuaian dengan nilai-nilai yang terdapat dalam Al-Qur'an.

\section{KESIMPULAN DAN IMPLIKASI}

Berdasarkan penelitian yang telah dilakukan di BTN Syariah dan BJB Syariah dan analisa mengenai konsep service excellence perbankan syariah, maka dapat disimpulkan bahwa :

a. BTN Syariah dan BJB Syariah memiliki Standar Operasional Prosedur (SOP) dalam memberikan pelayanan kepada nasabah. SOP tersebut berbentuk buku yang berisi rincian teknis pelayanan yang mencakup visi dan misi pelayanan, prosedur pelayanan, penampilan karyawan, attitude karyawan, prasyarat pelayanan, ketentuan tarif, jenis layanan, kompetensi yang harus dimiliki karyawan dan sebagainya.

b. Al-Qur'an sebagai panduan hidup juga memberikan panduan (konsep) pelayanan perbankan syariah. Secara umum, konsep pelayanan berdasarkan Al-Qur'an dapat diterangkan sebagai berikut :

1. Karyawan bank syariah sebagai agen pelayanan perbankan syariah harus memperhatikan tiga konsep dasar pelayanan yaitu keikhlasan, kesuaian pelayanan dengan syariat, dan berusaha melayani dengan pelayanan terbaik (sungguhsunggguh). Keikhlasan merupakan syarat utama diterimanya amal seseorang, kesyariahan merupakan suatu kepastian dalam melayani, dan kesungguhan merupakan indikasi keikhlasan seseorang dalam beramal.

2. Bank syariah dalam memberikan pelayanan harus memenuhi kebutuhan karyawannya terlebih dahulu, sebelum memberikan pelayanan kepada nasabah. Hal ini merupakan ibrah dari surat Al-Baqarah ayat 44 yang menyatakan dalam berdakwah kita tidak boleh melupakan diri sendiri, artinya jangan sampai kita mendakwahkan orang lain sementara perbuatan kita tidak sesuai dengan apa yang didakwahkan.

3. Pedoman yang diberikan AlQur'an dalam memberikan pelayanan kepada nasabah yaitu karyawan harus mencontoh bagaimana Rasulullah SAW melayani pelanggan-Nya ketika berdagang (surat Al-Ahzab ayat 21), melayani nasabah dengan lemah lembut, memiliki sifat pemaaf, menyelesaikan masalah dengan musyawarah, dan memiliki tekad yang kuat dalam memberikan layanan, tawakkal terhadap hasil yang akan dicapai (surat Ali Imran 159). Karyawan juga harus menyapa nasabah dengan baik, memberikan kecepatan dalam melayani, melayani dengan ikhlas, menjaga penampilan dan kebersihan, dan sabar dalam melayani (surat Al-muddatstsir ayat 1-7). Selain itu, bank juga 
harus menerapkan metode dakwah Rasulullah SAW dalam menarik minat, dan membina nasabah yaitu Al-hikmah, AlMau'idzah bil Hasanah dan AlMujadalah Bil Hasanah (surat An-Nahl 125).

c. Konsep service excellence yang diterapkan di perbankan syariah saat ini memiliki kaitan yang sangat erat dengan konsep service excellence yang ada dalam $\mathrm{Al}$ Qur'an. Perbankan syariah dalam memberikan pelayanan telah menerapkan banyak nilai-nilai yang terkandung dalam Al-Qur'an seperti bersikap lemah lembut kepada nasabah, memastikan kehalalan produk yang dijual, memaafkan nasabah dan sebagainya. Akan tetapi dalam memberikan pelayanan ada beberapa hal yang perlu diperhatikan oleh perbankan syariah yaitu bank syariah tidak boleh membedakan pelayanan antara nasabah prima dan nasabah biasa, serta bank syariah harus memberikan niat tulus ikhlas karena Allah, karena pelayanan yang terkesan baik tidak akan dianggap amal shaleh apabila tidak diniatkan secara ikhlas kepada Allah SWT.

d. Perbankan syariah telah mengimplementasikan banyak nilai-nilai konsep service excellence yang terdapat di dalam Al-Qur'an, hal ini disebabkan karena banyaknya kesamaan antara konsep service excellence perbankan syariah saat ini dengan konsep service excellence yang terdapat dalam Al-Qur'an. Implementasi konsep service excellence Al-Qur'an pada pelayanan perbankan syariah misalnya berdo'a bersama sebelum memulai pekerjaan, berusaha memastikan kehalalan produk yang dijual, adanya SOP yang melarang bersentuhan tangan dengan nasabah yang bukan muhrim dan sebagainya.

\section{DAFTAR PUSTAKA}

Abdullah, Muhammad. 2008. Lubabub Tafsir Min Ibni Katsir : Tafsir Ibnu Katsir, Alih Bahasa Oleh M. Abdul Ghaffar dkk. Jakarta : Pustaka Imam Syafi'i.

Alhifni, Anas. 2012. Persepsi Santri Terhadap Perbankan Syariah. Bogor : Fakultas Ekonomi dan Bisnis Syariah Universitas Djuanda.

Sulfianto, Arif. 2006. Al-Qur'an Dan Kepuasan Pelanggan Bank Syariah, Jogjakarta : UIN Sunan Kalijaga.

As-Sa'di, Abdurrahman, 2005. Taisir AlKarim Ar-Rahman : fi Tafsir Kalam Al-Mannan. Beirut/Lebanon : Al Resalah Publisher.

Bank Tabungan Negara, 2012. Annual Repot Bank Tabungan Negara tahun 2012. Jakarta : Bank Tabungan Negara.

Bank Jabar Banten Syariah, 2012. Annual Report Bank Jabar Banten Syariah tahun 2012. Bandung : Bank Jabar Banten Syariah.

Bank Tabungan Negara, 2011. Kamus Kompetensi Bank Tabungan Negara. Jakarta : Bank Tabungan Negara.

Departemen Agama RI, 2009. Al-Qur'anul Karim Wat-Tafsir : Al-Qur'an dan Tafsirnya jilid 10. Jakarta : Departemen Agama RI.

Finalis $1^{\text {st }}$ IsEFEF, 2012. Seminar Proceeding The $1^{\text {st }}$ Islamic Economic and Finance Research Forum: New Era of Indonsia Islamic Economic. Jakarta : 
Ikatan Ahli Ekonomi Islam (IAEI).

Gunara, Thorik, 2007. Marketing Muhammad : Strategi Handal dan Jitu Praktek Bisnis Rasulullah SAW. Bandung : PT. Karya Kita MadaniA Prima.

Hasan, Ali, 2010. Marketing Bank Syariah : Cara Jitu Meningkatkan Pertumbuhan Pasar Bank Syariah. Bogor : Ghalia Indonesia.

Hasbi, Ash-Shadiqiey Muhammad, 2010.'Ulumul Al-Qur'an : IlmuIlmu Pokok Dalam Menafsirkan Al-Qur'an. Semarang : Pustaka Rizki Putra.

Nadzir, Moh. 2009. Metode Penelitian. Bogor : Ghalia Indonesia.

Nurhayati, Sri. 2009. Akutansi Syariah di Indonesia. Jakarta : Penerbit Salemba Empat.

Qutub, Sayyid. 2008. Tafsir fi Dzilalil Qur'an di Bawah Naungan Qur'an Jilid XII diterjemahkan oleh Ahmad Yasin dkk. Depok : Gema Insani
Sapri, Suherman, 2013. Kiat Sukses Seorang Pemasar Bank: Tangibel menjadi Intangible. Bogor : PT. Penerbit IPB Press.

Subanda, Sudrajat. 2005. Dasar-Dasar Penelitian Ilmiah. Bandung: CV Pustaka Setia.

Kamilah, Rahmah. 2013. Strategi Pemasaran Produk Pembiayaan Wirausaha Syariah dalam Pengembangan Usaha Mikro di Kota Bogor (Studi BNI Mikro Syariah PGB Cabang Bogor)". Bogor : Fakultas Ekonomi dan Bisnis Syariah Universitas Djuanda Bogor.

Karim, Warman, Adi. 2004. Bank Islam : Analisis Fiqh dan Keuangan. Jakarta : PT. Rajagrafindo Persada.

Zuhaily, Wahbah, 2003. At-Tafsir Al-Munir : Fi Al-Aqidah, Was-Syari'h Walmanhaj As-Saabi'. Demaskus : Darul Fikri 